\title{
Arte como instrumento de
}

\section{transversalidade}

Mônica Hoff

O relato descreve a experiência do projeto pedagógico desenvolvido pela Fundação Bienal Mercosul, que, embora se destine ao público escolar, não é voltado para o ensino de artes nas escolas. 0 foco da iniciativa são professores, alunos e comunidades e seu objetivo é transformar a arte num projeto de atravessamento, objetivo que questiona a organização disciplinar dos conteúdos ligados à arte, considerando esta como elemento que perpassa diferentes áreas do conhecimento e é por elas perpassada. As ações do projeto são desenvolvidas com vistas a subsidiar professores em sua prática e investigação diárias; oferecer à comunidade formação ampla e experimental, bem como compartilhar saberes e ações que resultam na democratização do contato com a produção artística.

Palavras-chave: Fundação Bienal do Mercosul; formação de professores; arteeducação 
Experience reports

\section{Art as a cross-over instrument}

Mônica Hoff

The report describes the experience of the pedagogical project developed by Fundação Bienal Mercosul, which, although it is intended to school public, is not focused on the teaching of arts in the schools. The focus of the initiative are teachers, students and communities and its purpose is to transform art into a cross-over project, a purpose that challenges the disciplinary organization of artrelated contents, considering it as an element that crosses over different fields of knowledge and is crossed over by them. The actions of the project are developed with the purpose of subsidizing teachers in their daily practice and investigation; offering the community broad and experimental background, as well as sharing knowledge and actions that result in the democratization of the contact with artistic production.

key words: Fundação Bienal do Mercosul; teacher education; art-education 


\section{Arte como instrumento de transversalidade}

MônICA Hoff *

Arte, educação e campos do conhecimento.

\section{Embora tenha o público escolar como principal objeto} de seu trabalho, o Projeto Pedagógico da Fundação Bienal do Mercosul não trabalha, exatamente, com o ensino da arte nas escolas. Suas ações e seu pensamento se estabelecem no âmbito das micropolíticas situacionais, locais e regionais, a partir de experiências informais. Cada ação é definida a partir do estudo caso a caso.

Essas experiências, embora envolvam, na maioria das vezes, professores e estudantes, acontecem também com redes comunitárias, a partir de experiências colaborativas. 0 foco do projeto pedagógico não é o lugar no qual as relações são estabelecidas, e sim as próprias relações. São os agentes (professores, estudantes, comunidade) que movimentam o projeto e que fazem dele um processo dinâmico e transversal.

O projeto pretende subsidiar o professor em sua prática e em suas investigações diárias; ao mesmo tempo, se propõe a dar conta de uma série de outras atividades que giram em torno da comunidade, objetivando uma formação mais ampla e experimental.

Não acreditamos na arte como disciplina, e sim como ferramenta de atravessamento. Reconhecemos o importante papel político da criação da disciplina de Educação Artística para o currículo escolar - esse movimento é inquestionável e devemos muito a ele. No entanto, defendemos que o modelo tradicional não funciona mais.

Dar à arte a insígnia de disciplina é transformá-la em uma coisa que ela não é. Limitar a experiência artística, esse processo crítico e poético, ao formato de uma disciplina parece contrariar as premissas da própria arte. $\mathrm{E}$, por isso, buscamos, cada vez mais, no projeto pedagógico, fazer uso de metodologias artísticas (com forte ca-

\footnotetext{
* Mônica Hoff é coordenadora executiva do Projeto Pedagógico da
} Fundação Bienal do Mercosul. pital pedagógico) para desenvolver ações experimentais e informais com o público escolar.

No que se refere às referências conceituais, o projeto pedagógico não segue uma linha única e rígida. Com a realização, a cada dois anos, de novos projetos curatoriais, em razão das mostras, o projeto pedagógico é obrigado a se repensar e a se propor novas miradas e metodologias.

Assim, ao invés de uma linha única e fechada, trabalhamos a partir de diferentes ideias e autores que somados nos possibilitam um "outro" olhar sobre a arte, a educação e seus cruzamentos com diferentes campos de conhecimentos. Alguns dos autores com os quais nos identificamos: Paulo Freire, Jacques Rancière, Nicolas Bourriaud, Luiz Camnitzer e Marcos Villela.

Compartilhar saberes é uma das nossas principais propostas, considerando sobretudo que o contato de crianças e adolescentes com a produção artística é a própria valorização de uma cultura estética mais democrática. Nesse processo, a democratização acontece - seja o movimento em pequena ou grande escala. Possibilitar às crianças e adolescentes o contato com a produção artística é transformar o contato em experiência concreta; é abrir espaço para novas narrativas, novos olhares, tomadas de decisão até então impensadas e, sobretudo, para o compartilhamento de saberes.

\section{A arte atravessa e é atravessada}

Luiz Camnitzer, curador pedagógico da 6a Bienal do Mercosul, costumava dizer que era preciso ver a arte como educação e a educação como arte. Ou seja, a arte contendo em si um forte capital pedagógico e a educação entendida como potência poética e crítica.

Ao entender a arte como ferramenta e não como disciplina, podemos dizer que ela atravessa os processos de educação em todos os seus movimentos. A arte con- 
temporânea, por exemplo, que muitas pessoas dizem não entender, é matéria do hoje, do que vivemos no nosso dia-a-dia e, como tal, se alimenta dos mais diversos saberes e campos de conhecimento para existir - atravessa e é atravessada.

Ao mesmo tempo, sabemos que a educação é cada vez mais transversal, espontaneamente transversal, embora muitos não percebam. Em 2009, não há mais lugar para instituições e metodologias rígidas de ensino: a escola do século XXI é um espaço de experiência comunitária aberta aos diferentes saberes e metodologias.

Não podemos esquecer que, na escola, se vai ao dentista, se faz pré-natal, participa-se de oficinas de culinária, de capoeira, de marcenaria; se constroem sites e blogs, se dança e, também, se tem aula. Nessa escola, não existem apenas alunos e professores: há famílias inteiras, clubes de mães, times de pais, festas de bairro, missa e consulta médica.

A escola é palco de manifestações, sede de reuniões e espaço de exposição. É lugar de democratização de saberes. Não é por nada que as próprias experiências artísticas estão cada vez mais se estabelecendo em âmbito colaborativo, através de redes e vínculos sociais.

Nosso trabalho principal é sensibilizar crianças, adolescentes e jovens para as artes, falando a língua deles, propondo discussões inteligentes, não subestimando a sua capacidade, reciclando-se constantemente e, sobretudo, gerando ações interessantes para eles. As crianças, adolescentes e jovens lidam e se relacionam com a arte de uma maneira muito mais poética e sem preconceitos que os adultos.

$\mathrm{Na}$ nossa visão, professores e alunos formam um conjunto homogêneo, integrado. Tanto tanto professor quanto aluno são mediadores e detentores de saberes e ambos têm autonomia para se movimentar livremente em relação à arte.

No entanto, num sentido mais específico de mediação (no processo educativo, por exemplo), eu diria que o professor tem papel fundamental nessa relação, pois é dele a responsabilidade primeira de apresentar, despertar e seduzir. 0 encantamento provocado no aluno decorre, muitas vezes, da sedução do professor.

No entanto, não é dele a responsabilidade final. A mediação é um caminho de mão dupla, que pressupõe uma relação. E uma relação, por sua vez, pressupõe a participação de, pelo menos, dois elementos, dois pensamentos ou duas pessoas.

\section{Residências artísticas para professores e moradores}

As Formações de Professores são pensadas e construídas a muitas mãos. A metodologia é gerada a partir de avaliações de todas as ações do projeto pedagógico, do feedback dos professores e de discussões em grupo: trabalhamos com uma equipe multidisciplinar da qual fazem parte conteúdos das áreas de educação, artes visuais, literatura, filosofia, teatro e música.

Por exemplo, em 2007, iniciamos o processo de formações de professores no interior do Rio Grande do Sul e, em 2008, voltamos a essas cidades para uma nova formação, com conteúdo mais amplo e transdisciplinar. Isso foi possível porque analisamos o registro deixado pelos professores na avaliação feita em 2007. Com o tempo, aprendemos a importância de medir nossas ações para então estabelecer novas ações.

Até o momento, realizamos dois ciclos de formações de professores, em Porto Alegre e em pelo menos 40 cidades do interior do Estado. A primeira formação tinha como base os assuntos abordados pela 6 ${ }^{\mathrm{a}}$ Bienal do Mercosul; a segunda, desvinculada das mostras, pois aconteceu em 2008, projetou uma nova discussão, que possibilitava aos professores entender certas transições artísticas e relacioná-las com a contemporaneidade, a partir de recortes e períodos anteriores.

Os encontros, normalmente, têm duração de oito horas (ou um dia inteiro de trabalho) e são divididos em dois momentos: um mais teórico, na parte da manhã, em que o grupo participa junto; e outro, à tarde, em que o grupo se divide para participar de diferentes oficinas e discussões. Cada professor participa de, pelo menos, duas oficinas por encontro.

Em 2009, junto à $7^{\underline{a}}$ Bienal, as Formações de Professores ganharam uma nova cara e acabaram se transformando num Programa de Residências de artistas chamado Artistas em Disponibilidade: a educação como espaço para o desenvolvimento de micropolíticas experimentais.

Esse programa reuniu 14 artistas, em 12 projetos, que realizaram residências artísticas em mais de 20 cidades do Rio Grande do Sul. Ele se propunha dar continuidade às formações de professores através da tradução de projetos artísticos com forte capital educativo para um contexto socioeducativo. Nesse trabalho, em vez de envolver somente professores, acabamos mobilizando comunidades inteiras. 